\title{
Territorial Diagnosis of Ecotourism in Tunisian Mountain Protected Areas: Stakeholders, Positions and Power Relations
}

\author{
Boughamoura Olfa ${ }^{1,2,3} \&$ Samiha Khelifa ${ }^{3}$ \\ ${ }^{1}$ Laboratory of Sylvo-Pastoral Resources of Tabarka- Tunisia and LMI Mediter \\ ${ }^{2}$ UMR5044 - CERTOP Center of Study and Research Work Organization Power Toulouse \\ ${ }^{3}$ International Mixed Laboratory Mediterranean Terroirs: Heritage, Mobility, Change and Social Innovation \\ Correspondence: Boughamoura Olfa, Laboratory of Sylvo-Pastoral Resources of Tabarka- Tunisia, UMR5044 - \\ CERTOP Center of Study and Research Work Organization Power Toulouse and LMI Mediter. E-mail: \\ olfa.boug@gmail.com
}

Received: July 30, 2019

doi:10.5539/jsd.v12n6p103

Accepted: October 11, $2019 \quad$ Online Published: November 28, 2019

URL: https://doi.org/10.5539/jsd.v12n6p103

This work has been financially supported by these laboratories: Laboratory of Sylvo-Pastoral Resources of Tabarka- Tunisia, CERTOP (Center of Study and Research Work Organization Power) Toulouse and International mixed laboratory Mediterranean terroirs: heritage, mobility, change and social innovation.

\begin{abstract}
Since the 2000s, projects and studies have been multiplied for the development of ecotourism in Tunisian protected areas. Despite these efforts, the Tunisian case faces several failures. As part of this study, we aim to provide elements of reflection on a contractual scheme for a sustainable territorial development plan by ecotourism, around mountain protected areas in Tunisia. For this reason, we adopted the strategic prospective analysis revealing and analyzing the relationships between the different actors involved in ecotourism in the protected area. A Matrix of Alliances, Conflicts, Tactics and Objectives among MACTOR actors was developed in a participatory way to analyze the actors' strategies. After doing a triangular analysis which consists in to an inventory of the projects and studies about the protected area of Ichkeul and Cape Negro-Jbel Chitana, semi-structured interviews with personals from different sectors, we invited the actors met on the field or mentioned in the projects in a workshop organized in partnership with the General Directorate of Forests in Tunis in order to identify the different categories of actors and analyze the balance of power between them. This analysis is done through a matrix notation system. Eight categories of actors have been identified: international cooperation, resource managers, politic policy etc. Thanks to the matrix notation systems, we have been able in a participative way to classify these eight categories of actors into four types: dominant actors, relay actors, autonomous actors and dominated actors. Thus, the MACTOR method allowed us to identify actors who played a role in the development of ecotourism projects in Tunisia and to be able to diagnose their balance of power. This allowed showing the multidisciplinarity and complexity of the sector as well as the strong influence of certain actors such as international cooperation and public decision-makers. To conclude, the MACTOR analysis of the ecotourism actors in the protected area of Ichkeul and Cap Negro-Jbel Chitana enters into a methodology of prospective territorial analysis in this area to understand the points that caused the failure of several experiments.
\end{abstract}

Keywords: ecotourism, MACTOR, method, power relations, stakeholder analysis, strategies, protected area, Tunisia

\section{Introduction}

The forest and rural areas of the southern Mediterranean shore are the places most affected by economic marginalization following an imbalance in development between the regions (Gardin, 2004). Northern Tunisia is essentially mountainous regions covered by endemic forests, inhabited by a dense rural forest population, often considered as "a representation of poverty and underdevelopment" (Aderghal, 2007) where the poverty rate reaches $45.8 \%$ and an unemployment rate of $30 \%$ (Saadani, 2010).

The appropriation by the state of these spaces can be one of the causes that hinder its development. Indeed, the 
Tunisian forestry regime, inspired by a French policy based on state and administrative authority (described as a police officer by Morin, 2010), was established in 1881 with the creation of a forestry administration. The forests previously belonging to the Husseinite dynasty, only customary exploitation was carried out there by local residents; production and logging were established in 1883 by the French forestry administration. There was no private forest ownership and these areas remain a public commodity under the state and managed by forest agents. Shortly after independence in 1959, forest legislation was introduced under the pillars of nature conservation and forest areas at the expense of social development in these areas.

Paradoxically, these wooded areas constitute an important source of profit for the riparian populations in the traditional rural economy: land to be cleared to extend their crops, an important fodder source for their livestock, a source of energy for heating and cooking by collecting dry (or even sometimes tender) wood. Thus the resource has been subjected to a frank rivalry between the objectives of the forest regime and riparian needs, accentuated since the late 1970s by the establishment of the national network of protected areas to safeguard ecosystems at risk or unique. The creation of protected areas has supported nature conservation strategies to limit erosion risks, siltation of dams and to protect fragile, original or unique ecosystems. This network currently includes 44 areas, including 25 in the north and central part of the country in forest ecosystems (DGF, 2011). The protection of these areas was thus seen as an obstacle to productive activities and economic development for the population.

This competition over natural resources has created a rivalry between conservation and the anthropic pressure exerted by local people under the forest code, which prohibits any lucrative harvesting (DGF, 2011); the area is thus becoming a scene of struggle between strong and increasingly demanding anthropic pressure and a conservative and fixed forest regime.

Towards the year 2000, a social issue was developed among managers, towards a policy of integrating the population into conservation in order to reconcile economic development and biodiversity conservation. This paradigm shift occurred in the international movement towards sustainable development triggered by the signature by Tunisia of the three conventions of the Rio 92 conference and the elaboration of Agenda 21. The aim was to remedy the development imbalance between rural and urban areas and to develop forest areas sustainably. Thus, projects and studies with a view to developing an economic activity that generates profit is based on the enhancement of natural and cultural ecotourism resources have emerged. Ecotourism was a deliberate choice and a national strategy for the development of ecotourism in different protected areas was developed by the Ministry of Environment and Sustainable Development in 2007. Starting from the premise that ecotourism can be a means of rapid tourism of wealth in protected areas and generate rapid development of populations; the state has multiplied studies and projects in protected areas by collaborating with several national and international stakeholders. Despite these efforts, the ecotourism activity in this land is slow to develop to be attractive in a destination Tunisia known by the seaside tourism.

Indeed, the social awareness of these territories has created a change in the interveners' landscapes. The transition from an ecological defense policy to a sustainable development policy has led to the involvement of several types of stakeholders and a partial disengagement of the state (Krott, 2008). In fact, the development of ecotourism is a complex development, requiring a governance structure and stakeholder interaction (Duffy, 2008, Yeoman, and al., 2015). And considering Backman and Munanura, 2015 and Bonilla 2003 the stakeholders are the key to achieve development ecotourism.

Then its development involves many stakeholders, including as consumers, regional and national government, international institutions managers of protected areas, NGOs and local communities backman and Munanura, 2015). Then it can be considered as a strategy to help address economic and social problems in the aim of our research is to find a response to assess a dysfunction in the ecotourism development system. In this case we adopted an ecotourism diagnosis system, it consist to formulation of a judgement on the coherence of the territory and the mobilization of stakeholders (Lardon and Piveteau, 2005). We adopted a participative and representative method to do it for territorial description: structure analyzes and stakeholders. This paper is related to the stakeholder analysis part. We aim to identify who are the direct and indirect, dominated and dominant stakeholders of ecotourism development, to map the different interests, objective and relation and to assess the positioning and commitments of each actor in relation in order to confirm whether there is a certain imbalance in the commitment and involvement of the actors, so this may be one of the reasons that hinders the development of ecotourism, as it creates a failure in the governance system required to develop ecotourism in these territories and to found maybe if the poor stakeholder engagement, absence of well-integrated ecotourism plans and weak institutional arrangement is one of the reason to failed ecotourism projects (Rudovsky, 2015)?.Then we aim through a development of participative and representative exchange method they make it possible to map the 
complexity of actors and develop a tool to analyze the development of ecotourism in Tunisia using this method

\section{Materials and Methods}

\subsection{Choice of Protected Areas}

We choose two mountain protected areas: Ichkeul which is a national park created in 1980, whose physical delimitation is real with a strong presence of a state forest authority and the Cap Negro National Park created in 2010 (near the first figure No. 1) and in which the state can neither assert authority nor delimit space in a post-revolutionary context (Note 1). The two protected areas have been the subject of the greatest number of projects for development through ecotourism, especially since Ichkeul has been classified by UNESCO as a "Biosphere Reserve" since 1977, on its list of natural world heritage sites since 1979 and classified as a wetland of international ornithological importance (Ramsar) since 1980.Located in the north of Tunisia, these two areas contain a humid zone, a mountain and a dense forest with the presence of an agricultural and peasant activity. In both parks, the local population lives on state forestlands, subject to legal texts and a rigid legislative code designed for ecological preservation, which creates a conflict between social development and nature conservation.

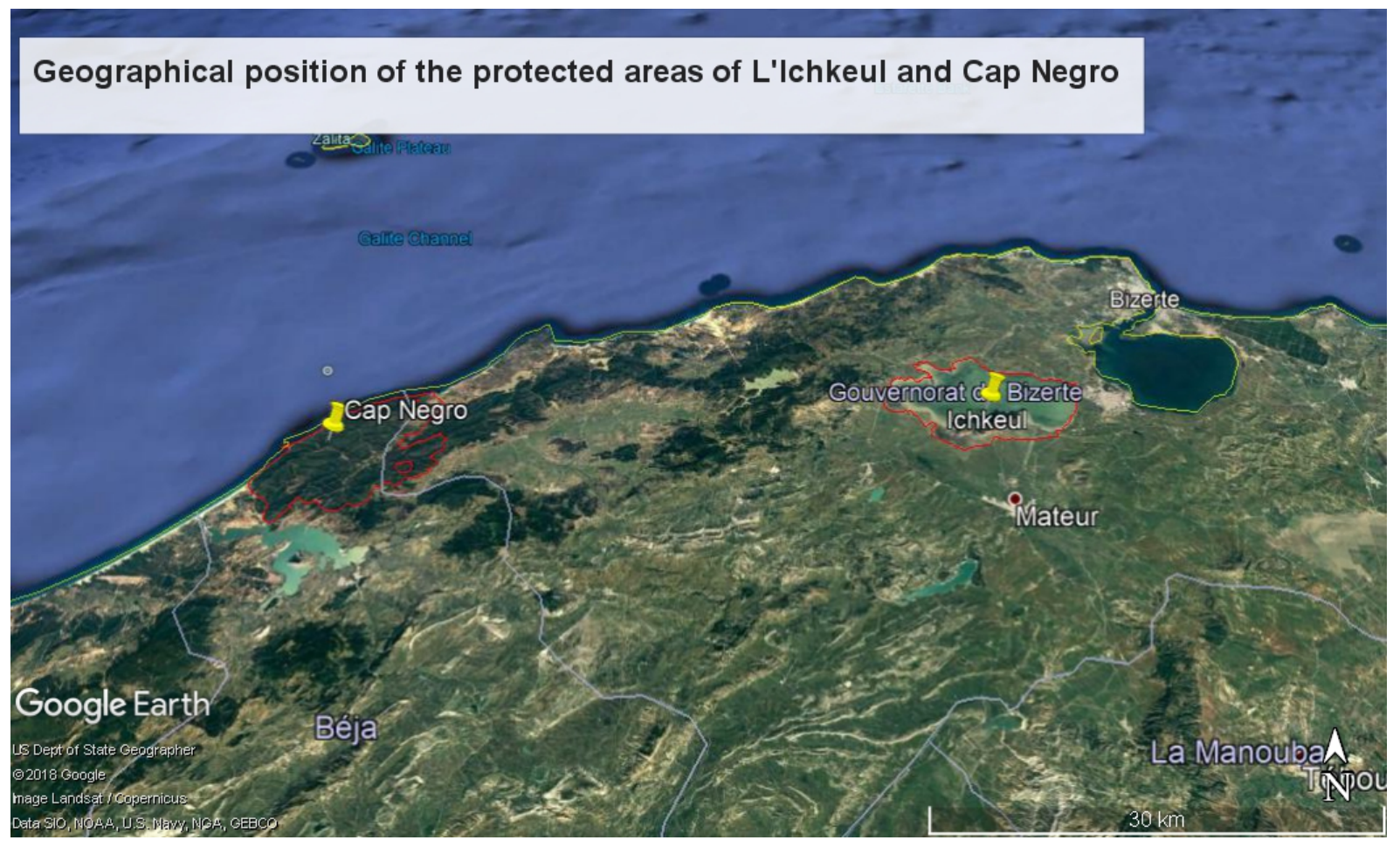

Figure 1. Geographical situation of the two protected areas Ichkeul and Cap Negro

\subsection{Stakeholder Analysis}

The methodology chosen for this research consists of a Mactor "actorial" diagnosis, which begins with the identification of the stakeholders or actors involved in ecotourism activity in the selected protected areas, their classification by group and finally an analysis of their games and their power relations (Amelot et al., 2009). This analysis tool aims to make visible the role of the actors, the conformity of their intervention with their objectives and the examination of their power relations. The power relation can be defined by Krott and al, 2013 as "the capability of an actor to influence other actors".

The Mactor was chosen because this work is part of a set of a participatory systemic analysis adopted by Michel Godet which consists in analyzing the sets of actors as well as analyzing the indicators of the ecotourism sector in Tunisia. Mactor was developed in 1990 by Michel Godet on the basis of a qualitative method of a stakeholders' strategy table previously developed in 1975, this method (commonly used) is modeled by the strategy and organization prospective investigation laboratory in the Mactor software. This analysis makes it possible to arrive at elements for reflection on the limits of a development experience (Chartier, 2016). 


\subsubsection{Identification and Categorization of Stakeholders}

It is an upstream work in an inventory of ecotourism stakeholders in two protected areas on three levels: national, regional and local. This work is based to a triangular approach of a qualitative data (observation, interviews and document analysis) is used in sociology in order to in order to conduct accurate studies (Neuman, 2014).

Open interviews with stakeholders previously identified based on a review of the 77 studies and projects for ecotourism development conducted between 1987-2017 in the two protected areas were conducted. Representatives, national and regional administrations, ministries of agriculture, tourism and environment and sustainable development were interviewed. Similarly, interviews were conducted with protected area managers, associations and NGOs and with the populations residing in the two protected areas in accordance with Table 1.

Table1. Number of interviews according to the three pre-established categories during the 1 st phase of the diagnosis

\begin{tabular}{lllc}
\hline Ladders & Type of actors & Institution & Number \\
\hline \multirow{2}{*}{ National } & International Actors & funders & 1 \\
& & NGO & 5 \\
\cline { 2 - 4 } & \multirow{2}{*}{ Departements } & Ministry of Environment and Sustainable Development Ministry of Tourism & 4 \\
& & Directorate General of Forestry & 4 \\
& & & 20 \\
\hline \multirow{2}{*}{ Regional } & Regional Directorates & Regional Forest District & 2 \\
& & Regional Directorate of Tourism & 1 \\
\hline \multirow{2}{*}{ Local } & Population & & 80 \\
\cline { 2 - 5 } & Managers & & 5 \\
\hline
\end{tabular}

Then we were able to build a bibliographic corpus of 77 projects funded by funders and NGOs for the period 1987-2017, as well as 58 scientific studies and research for the period 1975-2014. A list with the contact details of 72 stakeholders was thus established, including 10 ministerial executives, 8 regional executives, 16 international actors, 12 national associations, 12 active representatives of local populations, 7 research teams, 5 managers and 7 private entrepreneurs. These resource persons are involved in development actions through ecotourism in and around the two protected areas.

According to Freeman in (Aguera,2013) the term stakeholders means the actors "groups or individuals " that can affect or be affected by a sector's activities, basing to the example of definition many ecotourism author like Fennel and Weaver, 2008 Aguara, 2013, lequin 2001, scheyvens,1999, the ecotourism promote the participation of diverse type of stakeholders or actors even who are marginalized in other form of development like a private sector or community sector. Then the ecotourism is a multi-scale and multi-actor sector (Dimantis, 2018) so These actors were then categorized by categories, taking into account the actor's position in the governance scheme (international, national, regional or local) and the nature of his intervention (decision-maker, manager, economic operator, civil society and local population with reference these academic studies. 
Table 2. The categories of stakeholders identified

\begin{tabular}{|c|c|}
\hline $\begin{array}{l}\text { Policy and decision } \\
\text { makers }\end{array}$ & $\begin{array}{l}\text { Ministries and regional representations: agriculture, tourism, environment, culture, employment, } \\
\text { finance, territorial development, development and investment, national education (green class), } \\
\text { interior, women, youth and sports, General Directorate of Forests, National Agency for } \\
\text { Environmental Protection, The General Directorate of Land Management and Conservation, Tunisian } \\
\text { National Tourist Office. } \\
\text { Policymakers Parliament, Governorate, Regional Development Council, Delegation, Imadat }\end{array}$ \\
\hline $\begin{array}{l}\text { Resource } \\
\text { managers and } \\
\text { regulators }\end{array}$ & Regional agricultural development commissioner regional development office, museum manager \\
\hline Economic operators & $\begin{array}{l}\text { travel agencies, accommodation providers, craftsmen, fishermen, farmers, consultancy firms, } \\
\text { professional organizations and employers and trade unions, territorial animation offices, tourist } \\
\text { guides, hunters }\end{array}$ \\
\hline $\begin{array}{l}\text { Research and } \\
\text { training center }\end{array}$ & researchers, professors, students \\
\hline Support structures & Banks \\
\hline International actors & $\begin{array}{l}\text { World Bank, World Tourism Organization, Food and Agriculture Organization of the United Nations, } \\
\text { International Union for Conservation of Nature, other NGOs }\end{array}$ \\
\hline Civil Society & associations \\
\hline Population & Population \\
\hline
\end{tabular}

To characterize their power relations by type of actor, a workshop was organized on ecotourism actors in Tunisia, in partnership with the Directorate General of Forests, and to which all the interviewed speakers were invited. we considered that doing a joint workshop after the series of interviews and fieldwork is more appropriate: for one thing, the proximity of the two protected areas, given the number of actors in common in these territories, then, the low number of economic operators working on ecotourism in Tunisia and working in these two target territories, and finally the notoriety of this department which is in charge of protected area management and its place in the projects identified.

the composition of the workshop is as follows: 3 economic operators, 4 scientists, 9 international institutions, 9 ministry officials, 3 regional resource managers 5 local associations including 3 agricultural development groups.

Thus, we had a number of 32 participants from each type of actor but with a different representation: the most representative are political decision-makers and international institutions. According to Godet,2007 a workshop with approximately thirty people makes it possible to analyze and share ideas even if it is not always possible to find a consensus considering the differences in the balance of power. In our workshop there were certainly all the categories but the administrations and international institutions remain the most present which can perhaps show the degree of involvement and presence of the actors in the landscape of ecotourism development in Tunisia

it can also be observed that the local population is represented by members of agricultural development groups in these areas, this is undoubtedly due to the Tunisian strategy of supervision and standardization and development of the rural and forest population in the development of these areas

This first categorization of the actors into categories was submitted for opinion and amendment to these participants. The categorization of the stakeholders was discussed, amended and validated by the participants who categorized the actors according to Table 2. The agreed modifications have been made at this meeting.

\subsubsection{Analysis of the Influences between Stakeholders and Evaluation of Their Power Relations}

The analysis of the influences, direct and indirect, between the actors is a territorial diagnostic tool that is done through a matrix analysis. This makes it possible to position the categories of actors according to their relationship to others (influential, dependent, relay and autonomous) and to determine the strengths and 
weaknesses of each. The matrix of direct influences MID (category of actors*ategory of actors) (table 3 ) was distributed to all participants in the workshop on the actors of ecotourism.

Table 3. Matrix for evaluating the direct power relationships between stakeholders

\begin{tabular}{lllllll}
\hline $\begin{array}{l}\text { Actions from (row) Decision-maker } \\
\text { to (column }\end{array}$ & $\begin{array}{l}\text { RT Manager } \\
\text { and Regulator }\end{array}$ & $\begin{array}{l}\text { Economic } \\
\text { operators }\end{array}$ & $\begin{array}{l}\text { Research } \\
\text { and training }\end{array}$ & $\begin{array}{l}\text { Support } \\
\text { Structures }\end{array}$ & $\begin{array}{l}\text { actornational } \\
\text { actoril }\end{array}$ & $\begin{array}{l}\text { Customer } \\
\text { society }\end{array}$ \\
\hline Decision-maker & & & & \\
\hline $\mathrm{R} \quad$ Manager and & & & & \\
Regulator & & & & \\
\hline Economic operators & & & \\
\hline Research and \\
training
\end{tabular}

Individual time for reflection was given and then a pooling was made with discussions around divergent points until consensus was reached. A rating ranging from 0 to 4 was given to highlight the relationship between one group of actors and another (Godet, 2007).

- 4 : actor $\mathrm{i}$ can affect the existence of actor $\mathrm{j}$;

- 3 : actor i can affect the achievement of actor j's missions;;

- 2: actor $\mathrm{i}$ can affect the success of actor j's projects;

- 1: actor i can affect in a limited way in time and space the operational management processes of actor $\mathrm{j}$;

- $\quad 0$ : actor $\mathrm{i}$ has little influence on actor $\mathrm{j}$

The sums of influences in rows and columns reveal the most influential actors in the game and the actors most dependent on others.

Since relationships and interactions are not limited to determining the means of direct action because one actor can influence another actor through a third, an indirect MIDI influence matrix has been generated to highlight these relationships. The calculation of this matrix is done from the matrix of direct influences MID of a category of actors (aij) in the following way : (MIDI)ij $=\left(\right.$ MIDI)ij $+\sum \mathrm{k} \neq \mathrm{i}$ and $\mathrm{j}$ Min (MIDik, MIDkj)

The MIDI matrix makes it possible to identify direct and indirect influences of order 2 between actors. The interest of this matrix is to provide a more complete vision of the interplay of power relations (A actor can limit the range of choices of a second by acting on him through a relay actor). Using the "sum" operator for the MIDI calculation does not allow keeping in this new matrix the meaning of the intensity scale adopted to evaluate the direct influences in MIDI. The values contained in MIDI give, despite everything, a good idea of the importance of direct and indirect influences between actors. Two indicators are calculated from MIDI:

- The degree of direct and indirect influence of each actor (Ii, by summation on the lines) :

Ii : A coefficient of influence of an actor Ai which exerts it on all the other actors without taking into account the feedback of $\mathrm{Ai}$ on itself it is calculated as follows $\mathrm{Ii}=\sum \mathrm{k}$ MIDIik- MIDIii)

- The degree of direct and indirect dependence of each actor (Di, by summation on the columns) : Di : A coefficient that measures the dependence of one actor $\mathrm{Ai}$ i.e. the degree of influence that has received this actor from others without taking feedback into account as a precedent. The dependency is calculated as follows: $\mathrm{Di}=\sum \mathrm{k}$ MIDIki- MIDIii)

The Direct and Indirect Influences Matrix (MIDI) contains two types of interesting information:

- The direct and indirect influences that an actor $\mathrm{i}$ has on an actor $\mathrm{j}$ (MIDI)ij with $\mathrm{i} !=\mathrm{j}$ and which are equivalent 
(by definition) to the direct and indirect dependencies of actor $\mathrm{j}$ with respect to actor $\mathrm{i}$,

- The indirect influences of an actor $i$ on himself that pass through a relay actor and that we call feedback (MIDI)ii. The higher the influence, the lower the dependency and the lower the feedback, the greater the power balance of an actor. Indeed, only wanting to consider the relative influence of an actor to measure his power relationship is insufficient: an actor may very well have both a very strong influence, a very strong dependence and at the same time an important feedback: his power relationship will then be very weak. On the other hand, an actor with moderate influence but no dependence and feedback will have a significant power relationship. A coefficient called force ratio indicator Ri is thus calculated from the two coefficients $\mathrm{Ii}$ and $\mathrm{Di}: \mathrm{Ri}=((\mathrm{Ii}-$ MIDIii)/ $\left.\left.\sum \mathrm{iIi}\right)\right) * \mathrm{Ii} /(\mathrm{Ii}+\mathrm{Di})$. It is an indicator of the balance of power indicating that one actor is globally stronger than the others as long as his $\mathrm{Ri}$ is greater than 1 .

\subsubsection{Positioning of Stakeholders in Relation to Objectives}

It is a question of identifying the strategic stakes of all the actors in the development of ecotourism. Each issue can be declined in the form of one or more objectives on which the actors are allies, in conflict or neutral.

The objectives were identified by correlating the objectives of the projects, studies and research identified with the definition we take of ecotourism as a reference in this research: "environmentally responsible travel and visits to relatively undisturbed natural environments for the purpose of appreciating nature - as well as any past or present observable cultural manifestation of these environments, encouraging conservation, having a very limited negative impact and relying on the active participation of local populations with the aim of generating benefits" (Dudley,2008). The parts of this definition taken up by several other authors but also appears in the manual the Guidelines for the application of management categories to protected areas developed by the NGO . This NGO is well represented in Tunisia and in its development of its protected areas, 11 studies and projects carried out by its Mediterranean subsidiary were identified. These projects aimed to develop or benefit the development of ecotourism in these territories by using the same definition mentioned in the action plans or proposed guidelines such as the MEET project in 2013

A total of 20 objectives (Table 4) were set for this research.

Table 4. The objectives identified for the development of an ecotourism sector in protected areas

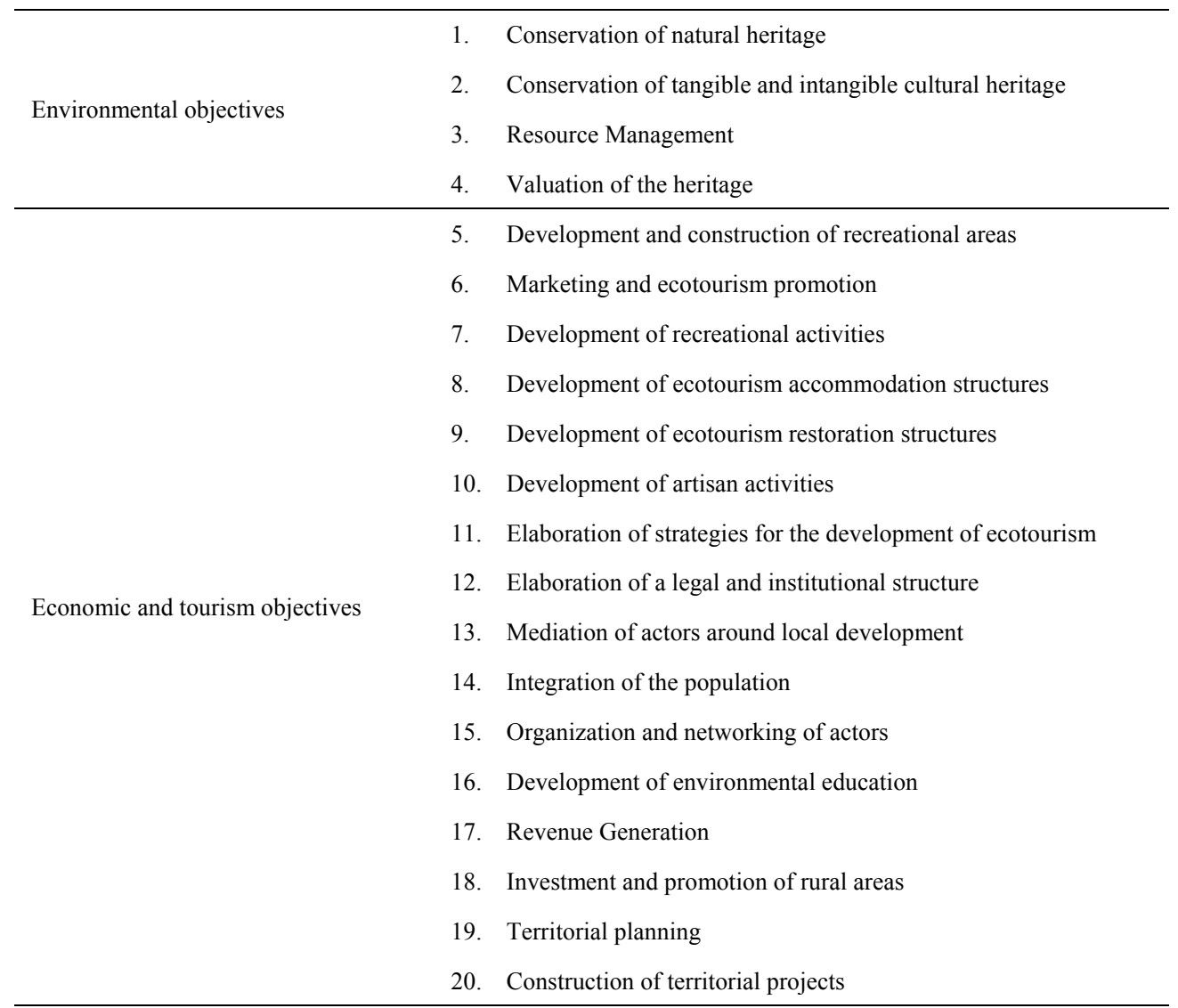


The positioning of each actor as well as the divergences and convergences with the other territorial stakeholders were calculated using a $2 \mathrm{MAO}$ matrix (Godet, 2007): actors * objectives (table 5)

Table 5. Matrix 2MAO actor *objective according to Godet (2007)

\begin{tabular}{llll}
\hline & Objective 1 & Objective ... & Objective 20 \\
\hline Stakeholder 1 & - & - & - \\
Stakeholder ... & - & - & - \\
Stakeholder 20 & - & - & - \\
\hline
\end{tabular}

Each participant in the above-mentioned workshop on ecotourism stakeholders completed his or her assessment individually:

- First of all, the categories valued position in relation to the objective: $(+)$ supportive, (-) opposite and (0) zero. This grid made it possible to identify a synthesizer matrix: the simple positions of objective actors* called $1 \mathrm{MAO}$ and calculated on the basis of the averages of the individual assessments given by the workshop participants.

- The hierarchy of 20 objectives per group of actors, giving an assessment ranging from 0 to 4 (detail below). A matrix of the positions evaluated for the $2 \mathrm{MAO}$ objectives* of actors, summarizing the averages of the records of all the participants, was then drawn up.

- $0:(+/-)$ the objective is small

- $1:(+)$ The objective involves the operational processes (management, etc...) of the actor /(-) is essential to its operational processes

- $\quad 2:(+)$ The objective calls into question the success of the actor's projects / (-) is essential to his projects

- $\quad 3:(+)$ The objective calls into question the fulfilment of the actor's missions / (-) is essential to his missions

- $4:(+)$ The objective calls into question the actor in his existence /(-) is indispensable to his existence

- A third matrix of the positions evaluated and weighted by the power relations of the 3MAO objective actors* category, was generated resulting from a weighting of the $2 \mathrm{MAO}$ matrix by the Ri coefficients.

Valuated objective positioning and force-weighted objective positioning balances were generated by the MACTOR 5.3.0 software.

\subsubsection{Data Input and Software Used}

The matrix of direct influences, and the matrices of the positions evaluated on the MACTOR version 5.3.0 software. After the manual input of the values collected or calculated from the individual records of the workshop participants, the calculations automated by the software allowed several visualizations of the results: direct and indirect matrices, MAO matrices, influence planes, influence histograms.

\section{Results and Discussion}

\subsection{Stakeholders}

The literature review and the 122 interviews conducted with the various ecotourism stakeholders in the two protected areas of Ichkeul and Cap Negro in northwest Tunisia made it possible to distinguish 3 levels of intervention: national, regional and local (Figure 2).

At the national level, international actors and public administrations working together have developed projects in both protected areas. The public representations concerned by the development of these territories are the Ministries of Agriculture, specifically the General Forestry Directorate, which is responsible for the management and conservation of protected areas, the Ministry of the Environment, which has a complementary role to the General Forestry Directorate, and the Ministry of Tourism, which accompany these two administrations in ecotourism projects. At the regional level are the regional administrations and conservators of these areas which are attached to the relevant ministries and support structures such as banks that can finance ecotourism projects in the region. This hierarchy of protected area management is due to the mode of governance of these territories 
which are publicly managed by foresters (DGF, 2010) and can also explain the positioning of international actors such as NGOs that usually operate locally and by collaborating with local authorities in many countries such as Australia (Gagnon and Gagnon, 2006).

And finally at the local level, there are the economic operators who carry out an activity within this area including the local population, the civil society present in the area and the researchers and ecologists who are concerned about the future of the areas so they appropriate the territories by acting locally without having recourse to authorizations at the national level most of the time (figure 2)

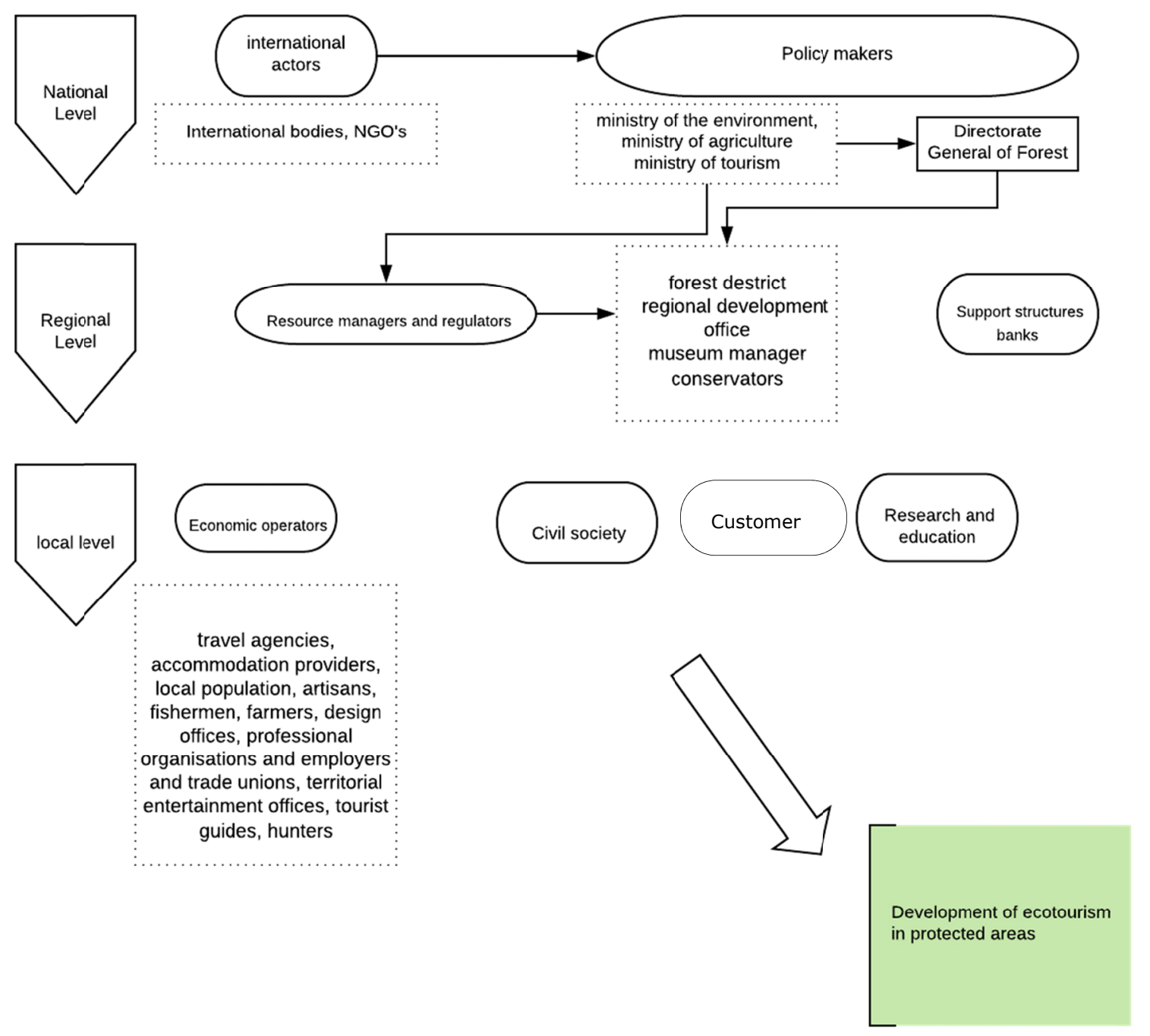

Figure 2. The levels of intervention of the stakeholders identified in the protected areas of Ichkeul and Cap Negro and involved in the development of ecotourism

Discussions with the 36 participants at the workshop on ecotourism stakeholders, during which the proposal of the 8 stakeholders, previously established and described in methodology, was amended and validated, led to agreement on the following categories (Table 6).

During the workshop, the population category was integrated into the civil society category given the organization of these populations in agricultural development groups considered by the state as associations. 
Table 6 . The categories of validated stakeholder

\begin{tabular}{ll}
\hline & $\begin{array}{l}\text { Ministries and regional representations: agriculture, tourism, environment, culture, } \\
\text { employment, finance, territorial development, development and investment, national }\end{array}$ \\
& education (green class), interior, women, youth and sports, General Directorate of \\
Policy and decision makers & Forests, National Agency for Environmental Protection, The General Directorate of \\
& Land Management and Conservation, Tunisian National Tourist Office. \\
& Policymakers Parliament, Governorate, Regional Development Council, Delegation, \\
& Imadat \\
\hline Resource managers and regulators & Regional agricultural development commissioner regional development office, \\
\hline Economic operators & museum manager \\
\hline Research and training centre & Travel agencies, accommodation providers, craftsmen, fishermen, farmers, consultancy \\
\hline Support structures & offices, tourist guides, hunters \\
\hline International actors & Researchers, professors, students \\
\hline Civil society & Banks \\
\hline World Bank, World Tourism Organization, Food and Agriculture Organization of the
\end{tabular}

\subsection{Analysis of the Influences between Stakeholders and Evaluation of Their Power Relations}

The matrix of direct influences between the MID categories of actors (table 7) made it possible to map the direct influences of the categories of ecotourism actors in the protected areas of Ichkeul and Cap Negro in Tunisia.

Table 7. Matrix for the evaluation of the direct power relations between the MID categories of stakeholders in ecotourism in the protected areas of Ichkeul and Cap Negro in Tunisia

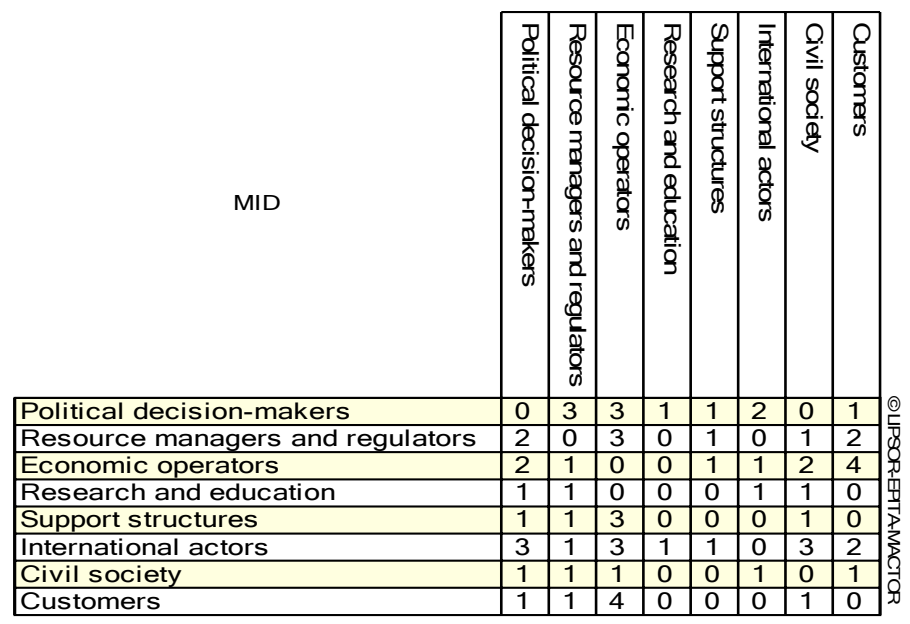

Indeed, it emerges that the customer category (ecotourists) has the highest influence (a value of 4) on ecotourism operators that can call into question their existence and vice versa; supply being closely linked to demand (Cairo and Le Masane, 2007). This category has little influence on decision makers, managers and international actors by calling into question in a limited way in time and space the operational management processes such as the 
development of protected areas.

This relationship of dependence can be explained by financing numerous projects; international actors (international bodies and NGOs) are thus in a strong position to choose and direct projects towards their strategic orientations. This category of actors exerts a balance of power of 2 on customers, since they have, in some projects, established the link between customers and the ecotourism destination via its economic operators. However, the influence of international actors on the categories of resource management, training and research and support structures seems to be limited in time and space with a value equal to 1 .

The category of decision-makers and policies registers an influence of a value of 3 on the managers and the economic operators thus calling into question the accomplishment of their missions; indeed, their power of legification, granting of the authorizations of exercise, strategic planning and planning and validation of the projects, granting them this influential posture. Decision-makers are the regulators of intervention in these protected areas. However, although reciprocal, the influence of decision-makers and politicians on international operators (with a value of 2) is lower than that of the latter on the former (3). Indeed, since they can hinder the success of projects carried out by international ecotourism bodies in the protected areas studied, decision-makers cannot call into question the fulfilment of the missions of international actors in Tunisia. Curiously, this study highlighted the total absence of influence of the category of decision-makers on the local population (active on the territory) and a weak influence on research, support structures and clients, calling into question, in a limited way, the operational management processes of these actors.

The resource managers seem to question the achievement of the missions on the economic operators having an influence value of 3 , by controlling the activities within the protected areas and by prohibiting any activity with productive and commercial vocation, thus applying the forest code elaborated by the DGF and updated in 2010 (DGF, 2010). They have a value of 2 influence on the decision makers who can, through their status and missions, influence the implementation and success of projects in the protected area. Protected area managers are responsible for implementing the actions of the guidelines issued upstream by national and regional decision-makers. Similarly, although authorizations are legally given nationally (by FMD), resource managers appear to have a direct influence of 2 on clients through the control of park entry and activities.

Table 8 also shows that the research and education group is the most independent and the least influential with no action on economic operators, clients and support structures. This weak relationship can be explained by the lack of collaboration between technicians and project developers and researchers in the ecotourism sector, the small number of researchers interested in ecotourism as opposed to what is happening in Western countries (Leroux, 2010) and the fact that this research remains poorly developed and marked by the absence of a proper theoretical framework (Tardif, 2003). The lack of links with the categories of economic operators, support structures and clients reveals a weak involvement in the development of ecotourism activities.

Civil society seems to have little weight in its balance of power with others stakeholders. Although it may call into question, in a limited way in time and space, the operational management processes of decision makers, managers, economic operators, international actors and clients, they have no influence on support structures or on research and training. Unlike other countries, where protected areas are managed by local communities (Lequin, 2001), the weak direct influences of civil society (in Tunisian protected areas) reflect a mode of local governance where they have little influence.

These power relations, marked by a strong influence of international actors and political decision-makers, and the strong dependence of the other categories, were confirmed by the dependence plan illustrated in Figure 3, which made it possible to classify each category of stakeholders into one of the four categories described in the research methodology: dominant, relay, dominated and independent.

- Dominants: an actor is said to be dominant when it has a great influence on the functioning of the other actors but only suffers it finely (GODET, 2007). In our case, international actors seem to have the greatest weight in the development of the ecotourism sector in protected areas. This by financing, collaborating and managing regional and national projects concerning the conservation of ecosystems and territorial development in rural areas such as : the integrated forest management project financed by the Japanese bank in 2000, or the development project for mountainous and forested areas in the north-west financed by the World Bank in 1993 or the ecotourism development projects in several Tunisian protected areas such as the MEET (The Mediterranean Experience of Ecotourism) project of the International Union for Conservation IUCN in 2015, Ecotourism in rural forest areas financed by the German GIZ cooperation in 2015.

- Relay: which exerts a strong influence on all the other types of categories but they are very influenceable by the dominant category: International actors. In this study, the category that positions itself as such are the 
national administrations and ministries this can be explained by their projects and studies developed in collaboration with the help of international actors either technically or financially.

- Dominated: This category includes the categories of economic operators, customers, territorial resource managers and civil society (Figure 3 ). They are actors who suffer a strong influence from the dominants and relays without exercising any in their turn. They are dependent, in their actions, on decisions taken at a central level and in which they are often excluded because of the centralized governance scheme. Projects, and by definition the actions programmed in them, are often designed by central administrations in collaboration or under the dictates of donors. "The country's development orientations and methods are characterized by internal political issues, issues of balance between rural and urban areas, and broad support from international organizations and donors. "(Canesse, 2014). This process of non-advisory development during the reign of Bourguiba attempted to integrate local populations and economic operators into the development process, in application of the political choice of the second presidency ("the change" of 1987) after independence (which took place in 1956) and whose guiding principle was "the rule of law". A "specific normative production" (Lascoumes, 1990) thus appeared in the early 1990s, bringing to light the so-called "participatory" approach, reducing the involvement of local populations in planning or restitution workshops. Handicapped by the lack of information or by transversal negotiation and argumentation skills, the involvement of territorial actors has remained ineffective and these categories of actors have remained with little influence on the key categories of ecotourism. The success and relevance of the intervention of actors other than decision-makers in the design, implementation and monitoring of projects being highly dependent on the nature of the links between the various actors, the participatory approach has shown its limits in the absence of an "emancipatory advantage" of the premises through access to information and means of free expression (Khelifa, 2014).

- Autonomous: The category of autonomous actors is that of stakeholders having no influence on the development of the ecotourism sector in the two protected areas of Ichkeul and Cap Negro. It brought together the support structures and research and training categories. This observation calls for reflection on the role of research in the design of ecotourism products, revealing that training at all levels, and even less research, does not currently seem to directly guide territorial development projects or the development of ecotourism products in these protected areas. However, many researchers and trainers act as experts with international donors and actors, thus putting the benefits of research (which fortunately remains very independent) to the benefit of the projects.

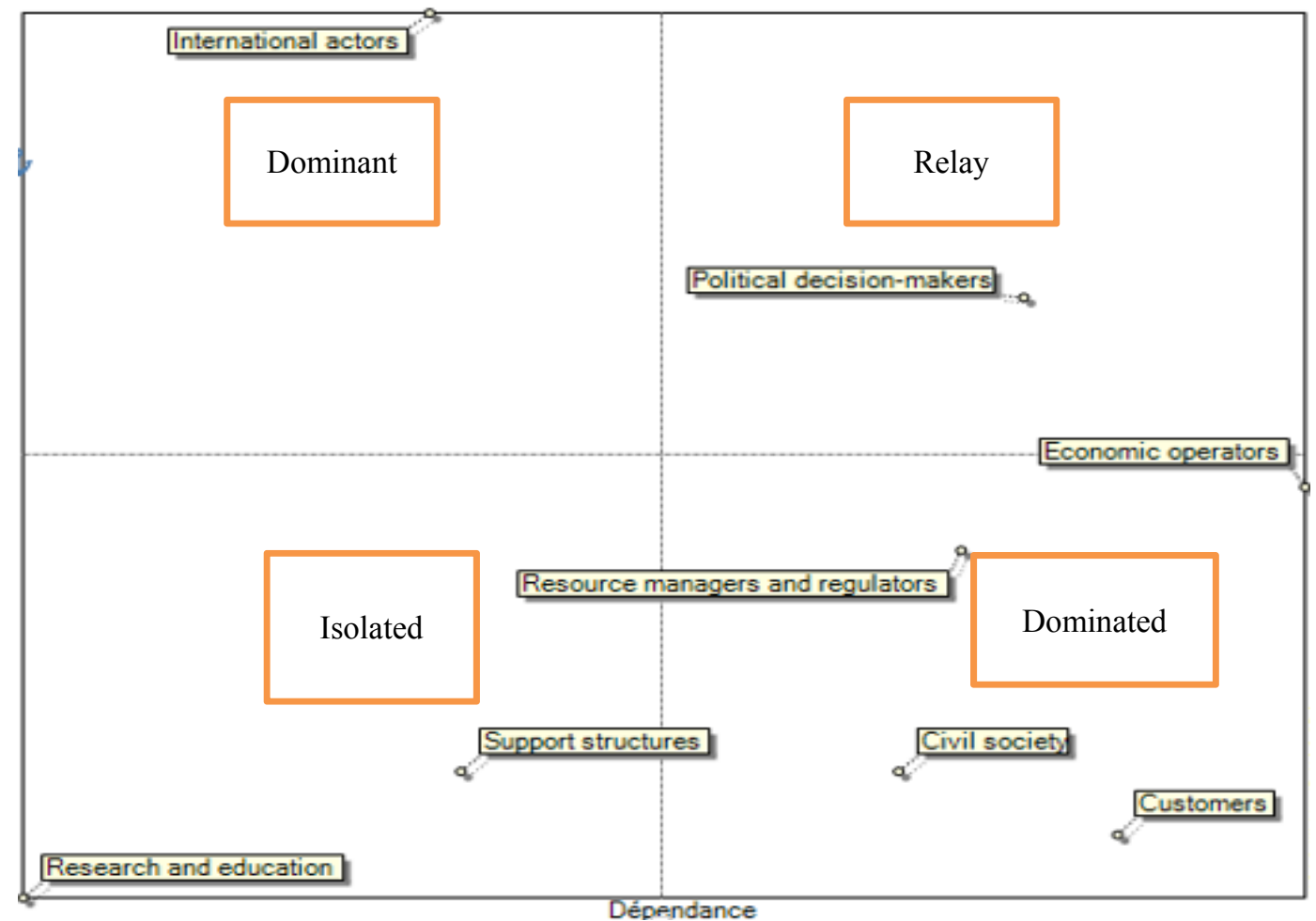

Figure3. Direct influence-dependence plan of the categories of stakeholders generated by the Mactor 5.0.3 software 
The indirect MDII influence relationships do not appear to change significantly from the direct MDI relationships between the categories of ecotourism stakeholders (Table 8). Indeed, international actors hold the greatest balance of power over other actors with an influence factor of 53 (dominant actor) followed by political decision-makers (relay actor) who have an influence factor of 44. The least influential remains the Research and Training group with a value of 25 , the Client with an influence factor of 27 and finally those of civil society and support structures with an influence factor equal to 29 .

As for the net dependency factor (table 8), they are distinguished by their strong autonomy far ahead of the other categories of stakeholders with an index of 11, followed by international actors (24) and support structures (25). However, economic operators (including ecotourism professionals), who represent the interface in direct contact with the market and customers, remain highly dependent on all other actors and more particularly on international actors, decision-makers and resource managers. Although government commitment is a condition for the success of tourism (Elliot, 1997), "the success of a destination depends intimately on the vision of the world it offers to travelers" (Vles, 2006). Is it possible to give a local and territorial vision of the world through projects and actions planned and conceived by actors who evolve in other worlds? This inventory can only limit the attractiveness of the Tunisian tourist offer and more particularly that of a sustainable tourism. Indeed, innovation, authenticity and distinction in relation to the existing are keys to the development of sustainable tourism products as described in the tourism product development manual published by the WTO in 2013. "Local tourism management today requires new organisational methods to be taken into account which must respect both the general interest and the profitability of the holding" (Vles, 2006). It remains to be seen whether the economic performance of ecotourism operators is one of the objectives of the dominant categories of decision-makers and international players? International institutions are very active in defining sustainable development guidelines that integrate an environmental, social and economic dimension, particularly in the countries of the South, and exert strong pressure in this direction (Amelo et al., 2009). In the same vein, NGOs intervene through studies and projects developed in collaboration with forest administrations, sometimes introducing concepts foreign to the particularities of the areas of intervention or even imposing choices poorly or not at all accepted by local populations (Guillaumet, 2016).

Table 8. The indirect MIDI dependency influence matrix generated by the Mactor 5.0.3 software

\begin{tabular}{|c|c|c|c|c|c|c|c|c|c|}
\hline MIDI & 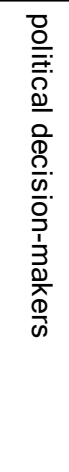 & 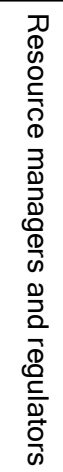 & 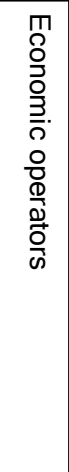 & 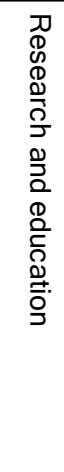 & 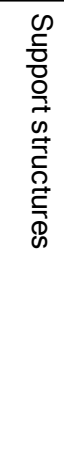 & 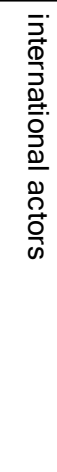 & 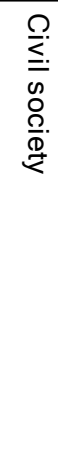 & 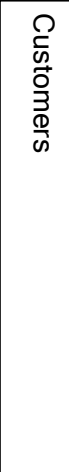 & 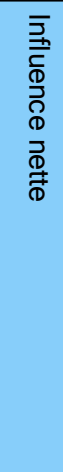 \\
\hline political decision-makers & 9 & 8 & 10 & 2 & 4 & 4 & 8 & 8 & 44 \\
\hline Resource managers and regulators & 7 & 6 & 9 & 1 & 3 & 4 & 5 & 7 & 36 \\
\hline Economic operators & 7 & 7 & 10 & 2 & 4 & 4 & 6 & 8 & 38 \\
\hline Research and education & 4 & 4 & 4 & 2 & 3 & 3 & 3 & 4 & 25 \\
\hline Support structures & 5 & 4 & 6 & 1 & 3 & 3 & 4 & 6 & 29 \\
\hline international actors & 10 & 9 & 11 & 2 & 4 & 5 & 9 & 8 & 53 \\
\hline Civil society & 5 & 5 & 5 & 2 & 4 & 3 & 4 & 5 & 29 \\
\hline Customers & 5 & 4 & 7 & 1 & 3 & 3 & 4 & 7 & 27 \\
\hline Dépendance nette & 43 & 41 & 52 & 11 & 25 & 24 & 39 & 46 & 281 \\
\hline
\end{tabular}

The $\mathrm{Ri}^{*}$ force ratio values calculated from the direct and indirect influences and dependencies and their feedback confirm the MID and MIDI conclusions (figure 4). The international players maintain their strong influence on the ecotourism sector with a $\mathrm{Ri}^{*}$ equal to 2.12 . This dominant position is probably due to the donor status most 
often enjoyed by international actors. In second position, there are public decision-makers with a Ri of 1.14 probably explained by the centralized decision-making model and Botton-up top-down governance. The strength ratio $\mathrm{Ri}=1$ of the research and training categorie strengthens our hypothesis of indirect valorization of research and training achievements through expertise and consulting. On the other hand, the balance of power of civil society over clients is probably declining because of the mode of governance that remains centralized by the state. The lack of consultative decision-making in protected areas hinders the development of ecotourism (Lequin, 2001).

Histogramme des rapports de Force MIDI

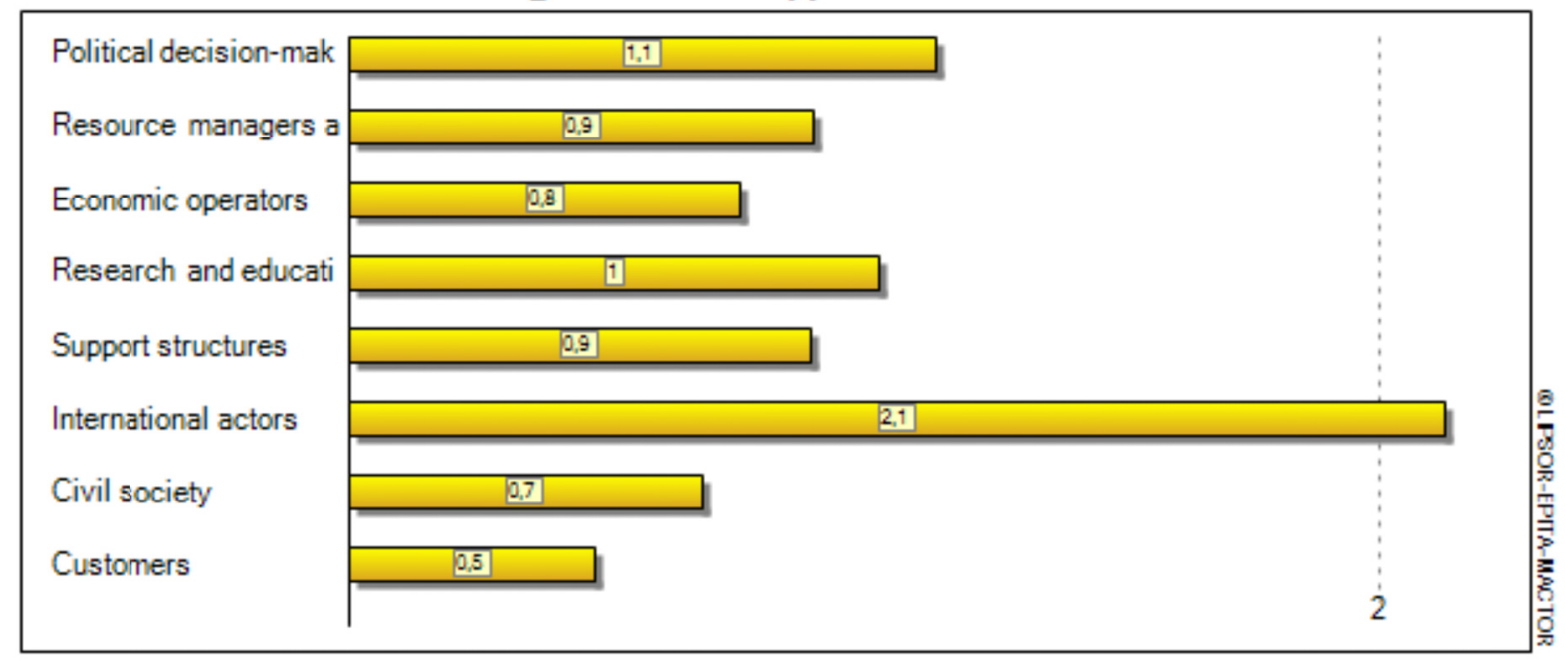

Figure4. Force ratio histogram $\mathrm{Ri}^{*}$ generated by the Mactor 5.0.3 software

\subsection{Positioning of Stakeholders in Relation to Objectives}

The positioning of the stakeholders in relation to the 20 objectives identified through the study of the 131 projects and studies, for the development of ecotourism, identified in the two protected areas of Ichkeul and Cap Negro, is illustrated in Table 9. It emerged that a consensus the four categories: decision-makers, managers, economic operators, support structures, economic operators are opposed to the achievement, existence of beyond three objectives, the rest of the categories are in favor of objectives for a development of ecotourism in protected areas. Six categories (decision-makers, managers, economic operators, support structures, national actors and clients) consider that more than three objectives are essential to their existence in the ecotourism sector or cause the accomplishment of their missions. Finally, only the research category has objectives that are not very consistent with their activities and apart from the protection of the resource does not seem to be concerned by ecotourism development. 
Table 9. The actor matrix * objective $2 \mathrm{MAO}$

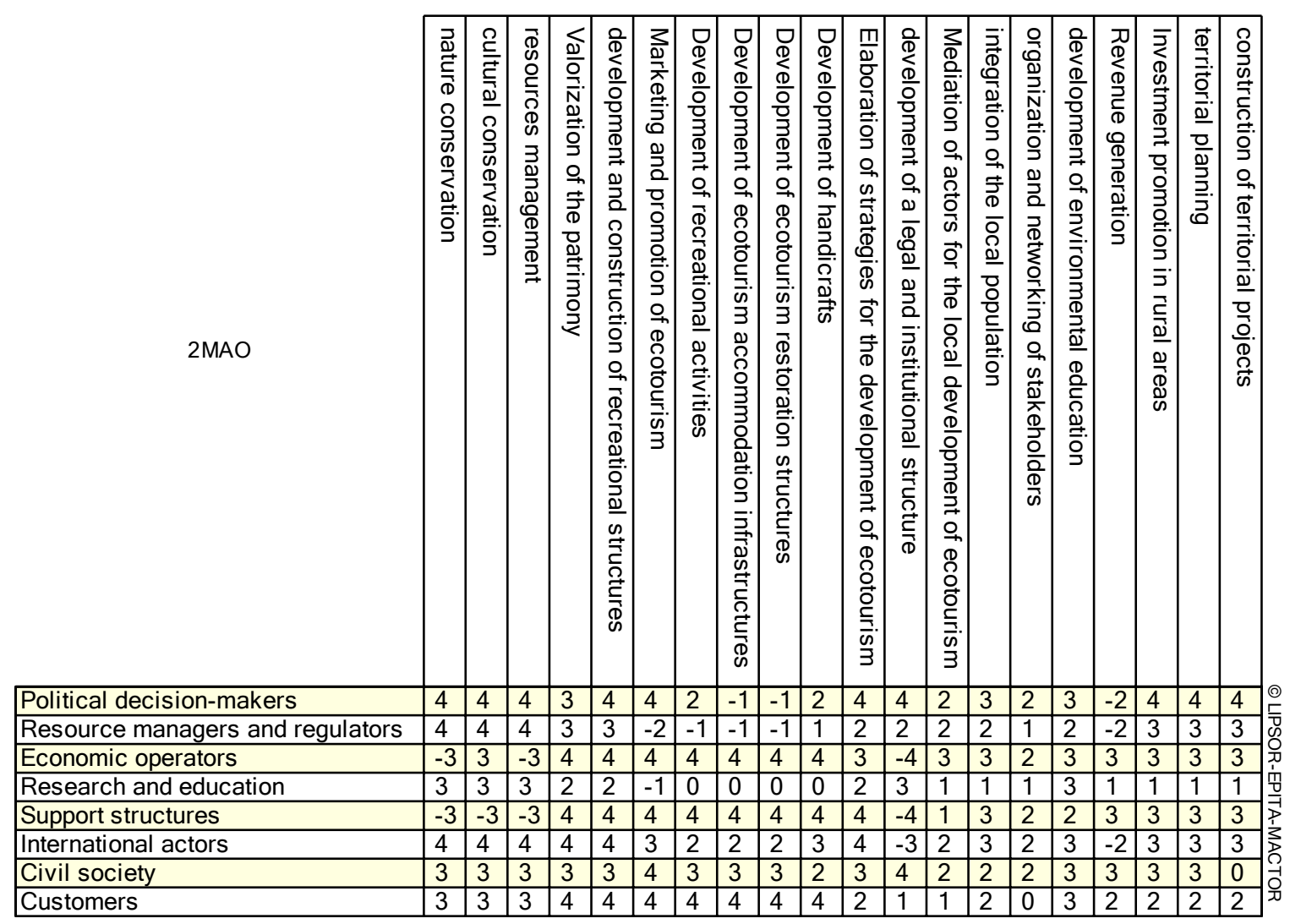

The matrix reveals that of the 20 objectives, 9 are the subject of differences between the categories of stakeholders. The positioning of the categories of actors in relation to the objectives of the projects carried out to develop ecotourism in protected areas, as perceived by the actors participating in this research, marked opposite distances for the following objectives:

- Development of a legislative and institutional structure

- Revue generation

- Resource management,

- Nature conservation,

- Marketing and promotion of ecotourism

- Development of recreational activities

- Development of ecotourism accommodation infrastructures

- Development of ecotourism restoration structures

It is interesting to note, first of all, the conflicting position of economic operators and support structures, close actors according to the diagram of distances between actors (Figure 5), in relation to the conservation and management of natural resources. We are in a classic pattern of pressure of mass tourism activity especially with a greater sensitivity for cultural resources. Secondly, the conflicting position of resource managers in relation to decision-makers - close actors (Figure 5)- in relation to income generation for local populations seems to us to be informative; indeed, the legacy of the policy of conservation and sanction of abstractions in the natural environment still seems to weigh on the perception of the role of these stakeholders. They are opposed to a strong presence of catering or accommodation structures in order to limit the pressure on these fragile ecosystems. Finally, it is interesting to underline the negative position of international actors and support structures with regard to the establishment of a legal and institutional framework. If the latter can resist by 
ignorance of the nature of ecotourism, the former could take advantage of a poorly structured context to conduct studies and experiment with improbable patterns of governance

Plan des distances nettes entre acteurs

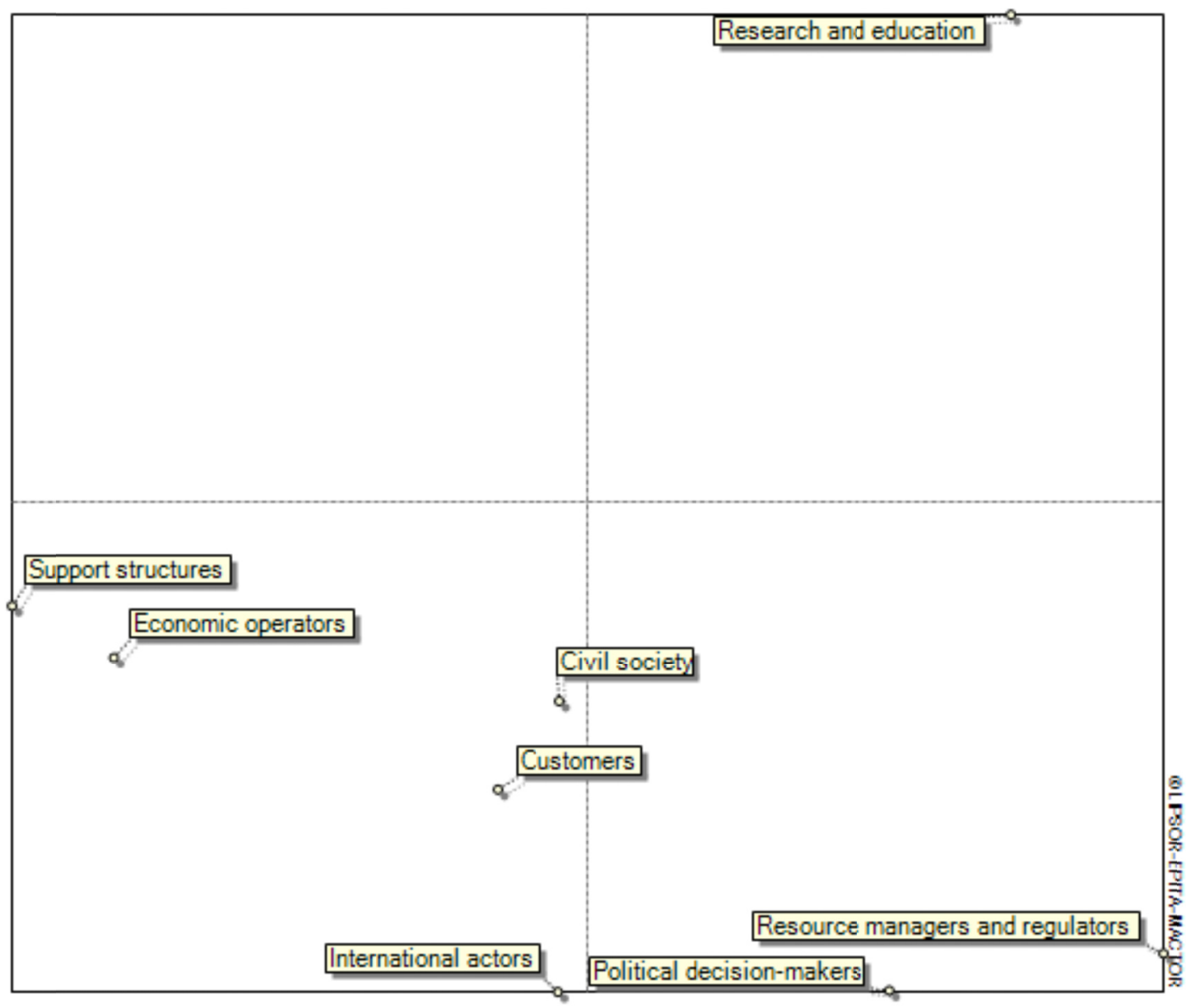

Figure 5. The plan of net distances between stakeholders

\section{Conclusion}

The diagnosis of the stakeholders of ecotourism in the protected mountain areas of Cap Negro and Ichkeul in Tunisia made it possible to identify 8 categories of actors, namely: decision-makers and politicians, resource managers and regulators, economic operators, support structures, research and training, international actors, civil society and clients.

This multi-stakeholder and multi-scale (local, national and international) pattern revealed differences in the degree of influence and dependence between them. International actors are the most influential actor in the development of ecotourism in the study areas. Next come public decision-makers (mainly national) because of the centralized mode of governance. The latter, despite their strong influence, are highly dependent on international actors for funding projects in protected areas. Economic operators, civil society, clients, and managers are very dependent actors on other actors, this analysis also highlighted the lack of commitment of researchers and support structures to the development of ecotourism. Finally, this research showed the positioning of stakeholders on 20 objectives identified in protected area projects, and identified the divergent points between stakeholders: the categories of economic operators and support structures that are against resource conservation, acting as actors of mass tourism, political decision-makers and managers who are against the development of a tourism structure and finally international stakeholders who oppose a change in a legal and institutional framework.

To conclude, the development of ecotourism remains a test sector conditioned by public decisions and donors in the areas managed by the state, even if there has been a construction of a network of stakeholders around this 
theme.

\section{Acknowledgements}

We thank the respondents we met in the field, whether in protected areas or in the Ministries, and for hosting us. We also thank the General Directorate of Forestry at the Ministry of Agriculture, which helped us to organize the workshop for ecotourism stakeholders in Tunisia.

\section{References}

Abdelkafi, J. (2005). Atlas des paysages de la Tunisie 331p.

Aderghal, M. (2007). Restructuring in Agro-Sylvo-Pastoral Systemsof Atlantic Morocco. In Getel J., \& Breuer I. (Eds.), Pastoral Morocco. Globalizing Scapes of Mobility and Insecurity. Wiesbaden.

Agüera, F. O. (2013). Stakeholder theory as a model for sustainable development in ecotourism. University of UTESA, Master in Business Administration. Seville: University of Seville.

Amelot, X. et al. (2009). Jeux d'échelles, jeux d'acteurs, jeux de mots. Approche comparée des politiques forestières en Guinée, à Madagascar et au Vietnam : de la colonisation à la globalisation, Colloque international GECOREV Gestion concertée des ressources naturelles et de l'environnement - du local au mondial - : pour un dialogue entre chercheurs, société civile et décideurs, Université de Versailles, Saint-Quentin-en-Yvelines, 26-27-28 juin 2006, Saint-Quentin-en-Yvelines.

Auclair, L. et al. (2004). La gestion d'un milieu forestier : entre intervention publique et stratégie paysannes, Environnement et sociétés rurales en mutation, Ird éditions.

Backman, K. F., \& Munanura, I. (2015). Introduction to the special issues on ecotourism in Africa over the past 30 years. Journal of Ecotourism, 14(2-3), 95-98. https://doi.org/10.1080/14724049.2015.1128058

Bonilla, J. C. (2003). Participatory Ecotourism Planning. Conservation international, 3-4, 46p.

Brenoux, P., Bion, J.-Y., \& Cohen, J.-C. (2001). L'analyse du système d'acteurs: diagnostic des territoires: cahier $\mathrm{n}^{\circ} 1$, CERTU, 100p.

Caire, G. et al. (2007). La mesure des effets économiques du tourisme international sur les pays de destination. Marché et organisations, 3(1), 63-88. https://doi.org/10.3917/maorg.003.0063

Canesse, A. (2014). Les politiques de développement en Tunisie : dans les participations et la gouvernance sous l'ère de Ben Ali, 80-86p,273p, archives contemporaines.

Diamantis, D. (2018). Stakeholder ecotourism management: exchanges, coordination's and adaptations. Journal of Ecotourism, 17(3), 203-205. https://doi.org/10.1080/14724049.2018.1502122

Direction Général des Forêts DGF. (2010). Code forestier et ses textes d'application. L'imprimerie officielle de la république tunisienne. $367 \mathrm{p}$

Direction Général des Forêts. (2002). Plan d'aménagement et de gestion du parc national Ichkeul. 154 p.

Dudley, J. (2008). Guidelines for the application of management categories to protected areas. IUCN Gland, Suisse, p5-8, p.96. https://doi.org/10.2305/IUCN.CH.2008.PAPS.2.en

Duffy, R. (2006). The politics of ecotourism and the developing world. Journal of ecotourism, 5(1-2), 1-6. https://doi.org/10.1080/14724040608668443

Elliot, J. (1997). Tourism. Politics and public sector management, Oxon, Routledge.

Fennel, D., \& Weaver, D. (2008). The ecotourism concept and tourism conservation symbiosi. Journal of sustainable Tourism, 373-380.

Gagnon, C., \& Gagnon, S. (2006). L'écotourisme entre l'arbre et l'écorce de la conservation au développement viable des territoires, presses de l'université du Québec, 414p.

Gardin, J. (2004). La forêt et l'État en Kroumirie : politique environnementale et contrôle social des populations rurales en Tunisie. Thèse de doctorat de Géographie, Université de Paris 10 Nanterre.

Godet, M. (1991). Actors' moves and strategies : the Mactor method. Futures, July-August. https://doi.org/10.1016/0016-3287(91)90082-D

Godet, M., Durance, \& Gerber, A. (2007). Strategic Foresight - La Prospective - Use and Misuse of Scenario Building, Cahier SR10.

Guillaumet, A. (2016). La place de la nature dans la société tunisienne les empreintes du politique sur 
l'environnement.

Institut national de statistique. (2014). Recensement général de la population et d'habitat national.

Khelifa, S. (2014). La Gouvernance entre le spécifique et le commun. Les Cahiers de l'OCEMO, Paroles d'experts du groupe de travail de l’Office de Coopération Economique Méditerranée-Orient. n³, p : 45-46.

Krott, M. (2008). Forest Government and Forest Governance within a Europe in change. The multifunctional role of forests-policies, methods and case studies. EFI Proceedings 55 p. 14-25p.

Krott, M., Bader, A., Devkota, R., Maryudi, A., Giessen, L., \& Aurenhammer, H. (2013). Actor-centered power: the driving force in decentralized community based forest governance. Forest policy and economics, 49, 34-42. https://doi.org/10.1016/j.forpol.2013.04.012

Lardon, S., \& Piveteau, V. (2005). Méthodologie de diagnostic pour le projet de territoire : une approche par les modèles spatiaux. Géocarrefour, 80(2), 75-90. https://doi.org/10.4000/geocarrefour.980

Lascoumes, P. (1990). Normes juridiques et mise en œuvre des politiques publiques. L'année sociologique, (40), 43.

Lequin, M. (2001). Ecotourisme et gouvernance participative, 40-80p ,254p presses de l'université du Québec.

Leroux, E. (2010). Vers un Tourisme Durable ou un écotourisme. Management \& Avenir, 34(4), $234-238$. https://doi.org/10.3917/mav.034.0234

Morin, G. (2010). La continuité de la gestion des forêts françaises de l'ancien régime à nos jours ou comment l'état a-t-il pris en compte le long terme. Revue française d'administration publique $2010 / 2 \mathrm{n}^{\circ} 134$, école nationale d'administration ENA. https://doi.org/10.3917/rfap.134.0233

Neuman, W. L. (2014). Social Research Methods: Qualitative and Quantitative Approaches. Relevance of social research, 8 .

Rudovsky J. F. (2015). The ecotourism industry is saving Tanzania's animals and threatening is indigenous people.

Saadani, Y. (2010). Les biens et services tunisiennes : état de lieu. Communication dans le projet AGOR atelier de concentration avec les partenaires. Maroc 1-2 juin 2010.

Scheyvens, R. (1999). Ecotourism and the empowerment of local communities. Tourism Management, 20(2), 245-249. https://doi.org/10.1016/S0261-5177(98)00069-7

Tardif, J. (2003). Écotourisme et développement durable, VertigO - la revue électronique en sciences de l'environnement, Volume 4 Numéro 1 | mai 2003, mis en ligne le 01 mai 2003. Retrieved from http://journals.openedition.org/vertigo/4575

Vles, V. (2006). Politiques publiques d'aménagement touristique. Objectifs, méthodes, effets, Presses universitaires de Bordeaux, Pessac, p 112.

Word tourism organisation. (2011). Handbook on tourism product development, 36-40, 174p.

Yeoman, I., Andrade, A., Leguma, E., Wolf, N., Ezra, P., Tan, R., \& McMahon-Beattie, U. (2015). 2050: New Zealand's sustainable future. Journal of Tourism Futures, 1(2), 117-130. https://doi.org/10.1108/JTF-12-2014-0003

\section{Note}

Note 1. A revolution happened in Tunisia on January 14, 2011; the country lives since then in a transitional post-revolutionary context.

\section{Copyrights}

Copyright for this article is retained by the author(s), with first publication rights granted to the journal.

This is an open-access article distributed under the terms and conditions of the Creative Commons Attribution license (http://creativecommons.org/licenses/by/4.0/). 